\title{
Bioethics education initiative in Pakistan
}

\author{
This article was published in the following Dove Press journal: \\ Medicolegal and Bioethics \\ 18 March 2016 \\ Number of times this article has been viewed
}

\section{Aamir Hussain \\ Department of Community Medicine, Liaquat National Hospital and Medical College, Karachi, Pakistan}

Correspondence: Aamir Hussain Department of Community Medicine, Liaquat National Hospital and Medical College, National Stadium Road, Karachi, 74800 , Pakistan

Tel +923332336984

Fax +92 $213414207 \mid$

Email dr.aamirhussain786@gmail.com

\section{Dear editor}

Revival of ethics is now becoming a universal phenomenon in every field of life. The realm of bioethics within the public health community is actually a prompt to handle the various apprehensions. More and more institutions and hospitals have been introducing a new or extended curriculum on this subject. ${ }^{1}$

In a population of an estimated 180 million Pakistanis, the literacy rate in Pakistan is only $57 \%$. As a consequence of deprived and pitiable investment in human development and improvement, our country has trailed behind, in contrast to neighboring countries, for instance, the People's Republic of China and India. Nonetheless, Pakistan is entering the domain of technology, ${ }^{2}$ and new technologies lengthen lifespans. This has prompted us to inquire about the value and worth of human life when the quality of life is uncertain. In addition, we are confronted with queries of whether some unborn lives ought to be cut short. Our novel versus novice technologies nurture questions about the significance of human life both in the initial and advanced junctures. ${ }^{3}$ As a result of the exponential growth of information and increased community awareness, it is now established that clinicians must, in addition to being competent and proficient in skills, provide relevant scientific knowledge. Health care providers make decisions within the framework of their own moral basis; this is learnt by the residents and becomes deeply rooted in the process of clinical decision making. ${ }^{4-6}$ Traditional medical training provides limited guidance to residents and medical students regarding ethical problems and difficulties in the "real world" encountered by health care leaders and health care professionals.

There are only two graduate level bioethics programs being offered in the country aimed at sensitizing the students and professionals to bioethical issues. One of them is from the Sindh Institute of Urology and Transplantation, Karachi with a Centre of Biomedical Ethics and Culture, which initiated a postgraduate diploma in bioethics in 2006 and a Master's program in 2009. The Aga Khan University Karachi started a Master's degree program in bioethics (MBE) in 2008 .

In bioethics education, students are deliberately sensitized to learn about ethical dilemmas covering autonomy, privacy, confidentiality, equity, justice, no harm, nonmaleficence, beneficence, non-discrimination, futility, informed consent, ascent, organ donation, legalization of illicit drugs, human rights, suicide, euthanasia, self-medication, medical and clinical errors, and others. ${ }^{8}$ But until recently, medical schools did not teach submit your manuscript $\mid$ www.dovepress.com

Dovepress

http://dx.doi.org/10.2147/MB.S104297
Medicolegal and Bioethics 2016:6 I-2

(c) (i) (5) 2016 Hussain. This work is published and licensed by Dove Medical Press Limited. The full terms of this license are available at https://www.dovepress.com/tterms.php (c) hereby accept the Terms. Non-commercial uses of the work are permitted without any further permission from Dove Medical Press Limited, provided the work is properly attributed. For permission
for commercial use of this work, please see paragraphs 4.2 and 5 of our Terms (https://www.dovepress.com/terms.php). 
ethics formally. Bioethics did not seem to have a place amidst instruction in anatomy, physiology, and clinical medicine. When moral issues did arise, medical students were supposed to learn by observing the behavior of the seniors, who had developed wisdom and good judgment due to years of experience. ${ }^{9}$ Because investigating bioethical issues is complex, we need to consider what knowledge needs to be developed in order for students to make sense of these issues, to be able to critically evaluate them, and to possibly take action based on this knowledge. ${ }^{10}$ From the 1970 s to the present, a steady stream of literature has insisted on the importance of ethics education and the need to establish an adequate ethics curriculum within medical schools, especially in Pakistan. ${ }^{11}$ Hence, a formal course on bioethics in all medical and dental institutions in Pakistan is highly recommended to start bridging the gap in this unique field.

\section{Disclosure}

The author has no conflicts of interest to disclose for this communication.

\section{References}

1. Caelleigh AS, Lane LW, Miles SH. Special issue: Teaching medical ethics. Academic Medicine. 1989;64(12):699-764.

2. Higher Education Commission- Pakistan. Annual Report for 2009-2010., Anonymous, (2010). Available from: http://www.hec.gov.pk/MediaPublication/NewsViews/PublishingImages/Annual\%20Report $\% 20$ for $\% 20$ Uploading/Annual\%20Report\%20for\%20Uploading.html. Accessed March 11, 2016.
3. Sutton A. Christian Bioethics: A guide for the perplexed. London: T\&T Clark; 2008.

4. Mattick K, Bligh J. Teaching and assessing medical ethics: where are we now? J Med Ethics. 2006;32(3):181-185.

5. Eckles RE, Meslin EM, Gaffney M, Helft PR. Medical ethics education; where are we? Where should we be going? A review. Acad Med. 2005; 80(12):1143-1152.

6. Roff S, Preece P. Helping medical students to find their moral compasses: ethics teaching for second and third year undergraduates. J Med Ethics. 2004;30(5):487-489.

7. Alam M, Rahman Z, Shah M, et al. Bioethics: Awareness, attitudes and opinions among University students and Faculty/Researchers. Pakistan Journal of Medical Sciences. 2012;28(4):1-6.

8. Jafarey AM. A degree in bioethics: an "introspective" analysis from Pakistan. Indian Journal of Medical Ethics. 2014;11(2).

9. Corlett JA. The Role of Philosophy in Academic Ethics. Journal of Academic Ethics. 2014;12(1):1-14.

10. Sadler TD, Zeidler DL. Patterns of informal reasoning in the context of socio-scientific decision making. Journal of Research in Science Teaching. 2004;42(1):112-138.

11. Veatch RM, Sollitto S. Medical ethics teaching: report of a national medical school survey. JAMA. 1976;235(10):1030-1033.

Dove Medical Press encourages responsible, free and frank academic debate. The content of the Medicolegal and Bioethics 'letters to the editor' section does not necessarily represent the views of Dove Medical Press, its officers, agents, employees, related entities or the Medicolegal and Bioethics editors. While all reasonable steps have been taken to confirm the content of each letter, Dove Medical Press accepts no liability in respect of the content of any letter, nor is it responsible for the content and accuracy of any letter to the editor.

\section{Publish your work in this journal}

Medicolegal and Bioethics is an international, peer-reviewed, open access journal exploring the application of law to medical and drug research and practice and the related ethical and moral considerations. The journal is characterized by the rapid reporting of reviews, case reports, guidelines and consensus statements, original research and surveys. The manuscript management system is completely online and includes a very quick and fair peer-review system. Visit http://www.dovepress.com/testimonials.php to read real quotes from published authors. 